\title{
Waterloo, and the de Lancey Memorandum
}

\author{
Major-General C. W. Robinson C.B.
}

To cite this article: Major-General C. W. Robinson C.B. (1910) Waterloo, and the de Lancey Memorandum, Royal United Services Institution. Journal, 54:387, 582-597, DOI: $\underline{10.1080 / 03071841009431944}$

To link to this article: http://dx.doi.org/10.1080/03071841009431944

曲 Published online: 11 Sep 2009.

Submit your article to this journal $\pi$

Џ Article views: 4

Q View related articles $\sqsubset$ 


\title{
WATERLOO, AND THE DE LANCEY MEMORANDUM.
}

\author{
By Major-Goneral C. W. ROBINSON, C.B.
}

THE Memorandum by Sir William De Lancey, Deputy Quarter Master-General of the Army under Wellington at Waterloo, in 1815, and entitled "Disposition of the Army at 7 o'clock a.m., June 16 th," is well known to all students of the IVaterloo campaign, and has formed a puzzling document to rery many.

Several circumstances have contributed to make it so, such as the death of its compiler, mortally wounded at Waterloo two days after it was written; the fact that we possess no original of it but only a copy; and lastly that until long after Waterloo no allusion was made to it.

Of recent years it has attracted more attention than otherwise ever would have been the case, because, both abroad and in England, it has been assumed as probable by several writers that it misled Wellington in his important letter to Blücher; written from the heights behind Frasne, near Quatre Bras, at 10.30 a.m. on 16th June; and also because it has been concemned-quite apart from the question of whether it misled Wellington or not-as a confusing, incorrect document, discreditable to its compiles and to Wellington's Staff.'

Ropes alludes thus to it :-

"That this 'Disposition' was relied on by Wellington when he wrote his letter to Blücher seems, by comparing the two papers, to be very clear" ; and describes it as,

"The most misleading statement ever drawn up for the information of a Commanding General" (Ropes, "The Campaign of Waterloo," $4^{\text {th }}$ Edition, 1906, and also previous one of 1893 , pp. 86 and 113 ).

Added to this, the letter to Blücher, based (as assumed above) upon this paper by Sir W. De Lancey, has been held by Continental writers, though upon no good foundation, to

1 See " Waterloo, a Narrative and Criticism," by E. L. Horsburgh, p. 50. Ropes" "The Campaign of Waterkoo" (1906), pp. 86-88, and 113; De Bas and Tserclaes de Wommercon "La Campagne de 1815 aux Pays Bas" (1908); W. O'Connor Morris "The Campaign of 1815" (1900), p. 98 , and many other writers of recent years. 
have deceived the Prussian Commander-in-Chief into fighting at Ligny, where he was beaten-a supposition which has widened further, in many minds the effect of this Memorandum.

Thus this Staff Memorandum by Sir WV. De Lancey, who was practically Chief of the Staff to Wellington, has become, through circumstances, both of historical consequence and of much interest, especially to British officers, although intrinsically it contains nothing of special value.

It seems, however, to the w'riter of these pages to be-to say the least-extremely probable that this "Disposition," or "Nlemorandum," has been simply misunderstood; that the usual interpretation put upon it has been erroneous; and that -for reasons given further on, the weight of which can be judged by all 1 -it has been condemned as incorrect, merely through a misapprehension of its meaning, and of the design of its compiler.

This view has been recently materially strengthened by reflection upon the double meaning which the title of the Memorandum will bear; by a careful comparison of Wellington's "Instructions to the Army on June 15th and 16th, 1815," as published in the ist Edition of the Wetlington Despatches. of 1838 , with those published in the revised Edition of 1852 ; and by a consideration, particularly, of the "Additional Instructions" issued to the Reserve in Brussels at 10 p.m. on 15 th June. These, it is to be noted, appear solely in the Edition of 1852 , and not in the earlier one, nor in the "Supplementary Despatches " of 186.3 -which are only " supplementary."

It is upon this account, and because the De Lancey Memorandum has attracted much unfavourable criticism, which reflects, perhaps very unjustly, upon the capacity of its compiler, a distinguished officer, who died of his wounds at Waterloo, that the writer ventures to think that the following remarks may be of service.

The Interpretation of the Menorandum now put forward can scarcely, he hopes, be deemed strained or unreasonable; and he would add that although it is simple, he has never himself hitherto seen it suggested, though perhaps it may have been so.

If there is any flaw in what is urged, military readers will soon detect it; if there is not, it will be a satisfaction to have contributed to place the Memorandum in a light more consonant

1 The niter appeals to the patience of his readers to follow arguments based necessarily upon various details. To save reference to books, the De Lancey .femorandum, and also "Wellington's Instructions to the Army," given on June 15th and 16 th (as published in the $18_{3} 8$ and also in the $185^{2}$ Editions of the Despatches), with the explanatory notes contained in these Despatches, have been placed on the Plate attached. If the reader will refer to this Plate as he reads, he will readily follow what is said.

VOL. LIV. 
than its usual interpretation does, with that ability which had been displayed by its compiler as a Staff Officer throughout the Peninsular War, and had led to his selection by Wellington to be Deputy Quarter Master-General of the Army in the Waterloo campaign.

Before discussing the purpose of the Memorandum it is convenient to state certain facts regarding it.

We possess, as has been said, no original of this paper, but only a printed copy of a copy, which in itself is likely to lead to misconception regarding the original. ${ }^{1}$ Our knowledge of it is entirely derived from a statement respecting it by General Sir De Lacy Evans, and from his copy of it, probably hurriedly jotted down. This copy with his statement ${ }^{3}$ as to it, together with copies he had made of Wellington's "Instructions for the movements of the Army on June 15th, 16th and I 7 th, 1815"-the originals of which Instructions were all lost, with Sir W. De Lancey's papers, at Waterloo-was sent by him years after the campaign to Colonel Gurwood, compiler of the Wellington Despatches.

It does not appear in the ist Edition of the despatches of 1838 , but does so in that of 1852 , and is given also in the Supplementary Despatches of 1863 .

Notes given in the Despatches, explaining how Sir De Lacy. Evans came to be in a position to make copies of the original "Instructions" (and it may be assumed of this Memorandum as xetl); and the manner in which the columns of the latter should be read; show this sufficiently clearly, and will be found on the Plate attached.

The copy of the Memorandum, as printed in the Despatches, has no headings to its columns, no entry of the hour when, or place where, the original was compiled, and no signature of its compiler.

Therefore, the Memorandum, if sent to.Wellington, had upon it something more than is in this copy; or, if given to him, was accompanied by a verbal explanation. The copy as we have it would, without Sir De Lacy Evans's statement as to it, be entirely incomplete, and doubtless is not in the exact form in which the original, without further explanation, would have reached Wellington.

It is, in no sense, an "Instruction" to the Army, although owing to the position in which it happens to have been printed in the 1852 Edition of the Despatches, in the midst of such Instructions, that impression may cccasionally have arisen.

1 See Notes beneath the Mcnorandum on Plate attached, as to discrepancies and errors, which creep into such opies of original documents.

- General Sir De Lacy Evans, a distinguished officer, saw much active service in the Peninsula, America, at Waterko, and in the Crimea, where he commanded a Division. He died in 1870 .

s Given on Plate attached. 
It should thus never be discussed and criticised, as it sometimes has been, apart from Sir De Latcy Evans's statement in explanation of its columns ; ${ }^{1}$ for he alone, so far as we know, in addition to Sir W. De Lancey himself, was aware of its purpose. We may, however, accept with confidence what Sir De Lacy Evans says, ${ }^{2}$ viz., that it was compiled by Sir IV. De Lancey for the information of the Commander of the Forces; and, under that statement, the view, which has occasionally been taken, that it was perhaps put together by some subordinate officer, can never be convincing or satisfactory.

It is most natural that Sir De Lacy Evans should have been, as he says, with Sir IV. De Lancey when the Instructions to the Army of $15^{\text {th }}$, 16 th and 17 th June were issued, and thus had the opportunity to copy them (and this Memorandum alsu), because it is mentioned in his Biography ${ }^{3}$ that he had "returned to Europe (from America) just in time to join IVellington's Army in Belgium, and was at once attached to the Staff of Picton's Division, then in Brussels, as Deputy Quarter Master General."4

He had been employed also in the Quarter Master General's Department in the Peninsular War, and in that with $A$ merica, which had just terminated, and after Waterloo was appointed Assistant Quarter Master General with the Army of Occupation. He had experience in the Quarter Master General's branch of the Staff, and at a time of pressure, such as that of the 15 th, 16 th and $17^{\text {th }}$ June, could be of service to Sir W. De Lancey, and might naturally have been called in, if available, to assist him, or may have gone to the Head Quarter Office for informalion for his own immediate Chief.

From the title and contents of the Miemorandum we can gather this (in some respects important) fact that it was certainly complcted, if not entirely put together, after $70^{\prime}$ 'clock a.m. on

1 Given on Plate attached, at the end of the Memorandum.

2 See Note below the Instructions for the Movements of the Army (as given in 1852 Fidition of the Despatches) on Plate attached.

"See Dictionary of National Biography, "Sir De Lacy Evans."

1 The more correct term nould no dombt be Assistant, or Deputy Assistant Quarter Master General. Ropes (p. 86) mentions that Sir De I acy Evans was in 1815 acting as Extra A.D.C. to Major-General Por:sonby, commanding a Cavalry Brigade-and this he apparently nas. Probably, however, he was on emergency made aviilable for nore than one duty-and as he was a .Major (becoming Lieut.-Colonel after IVater bo), his post as Extra A.D.C. Was temporary only. He says himself that he copied the Iristructions for the igth June from the Duke's writing, adding, "Saw the Duke write them while seated on the ground." (These Instructions for the igth June are mit given here, as they do not concern the Memorandum, but see Wellington Despatches, Vol. VIII., pige 144 of $\left.185^{2}\right)$.

3 We may gather, indeed, that it was commenced as neil as completed after 7 o'clock a.m., bccause the and entry in the Centre Column, "Braine le Comue," with reference to the and Division, was apparently entered about that hour, as the and Division was directed to Brainc ke Comte under order to Hill of 7 a.m., June 16 th. 
16 ih June, for this indicates that it was compiled not at letsure, but in haste.

At that hour the troops had left Brussels for the front; Wellington himself was about to set out for ()uatre Bras, ${ }^{1}$ and all was necessarily excitement and hurry.

It has bean generally assumed, though this is not certain, that Sir IV. De Lancey wrote the Memorandum in Brussels, and gave, or sent, it to iWellington just before the latter rode off to Quatre Bras, from beyond which place, at 10.30 a.m., he wrote his letter to Blücher.

Indeed, if $W$ ellington had read this Memorandum before he wrote that letter, the probabilities are that the assumption is correct; for he rode quickly to Quatre Bras, and thence went on to the heights behind (north of) Frasne, whence he despatched it. According to the Oldfield MSS., Sir WV. De Lancey. did not accompany him out of Brussels, remaining behind to write some orders; and he (Sir WV. De Lancey) is not alluded to as having been with Wellington at the interview with Blücher at Bry:"

Let us now consider the 'Title of the Memorandum, which vught to convey its intended purpose.

The words "Disposition of the Army at 7 o'clock, June 16th." will bear two entirely different interpretations, ${ }^{3}$ either of which might have been in the mind of the writer of ${ }^{4} t^{4}$ :-

I. The Disposal of the Army, in the sense of the arrangements made for it, and directions given to its various divisions, etc., under orders issued up to 7 a.m. inclusive.

2. The Position of the Army, in the sense of its situation, and the places its various divisions had reached at $7 \mathrm{a.m}$.

The accuracy of the Memorandum seems to depend upon which of these two interpretations expresses what was in the mind of Sir WV. De Lancey, who compiled it.

Under the first interpretation, the first line of the Memorandum would mean :-

The ist Division, which had been directed on Braine le Comte, is now marching to Nivelles and Quatre Bras.

1 The hour at which Wellington is said to have set out varies from 6 to $8 \mathrm{a} . \mathrm{m}$. on the $16 \mathrm{th}$, but 8 is that given by Lord FitzRoy Somerset, the Mlilitary Secretary. Probably he was in the saddle before 8 .

2 The Oldfield Miss. Nere kritten by Major John Odfield, Brigade Major R.E., during the Waterioo Campaign.

3 The wond "Disposition" is defined in the Dictionary as (1) the action of setting in order, arrangement; (2) the relative position of parts to a whole. (New English Dictionary-Muray and Bradlcy, Oxford, 1S97).

4The writer of the Title, as well as of the Memorandum itself, was presumably Sir IV. De Lancey; but by possibility Sir De Lacy Evans may have added the Title as well as his cxplanation to the Memorandum. 
Under the second interpretation, the first line would mean :

The ist Division, which was at (i.c., had reachcd) Braine le Comte, is now marching to Nivelles and Quatre Bras.

It will be seen that between the wo interpretations there is a radical difference.

Under the first interpretation, as we will endcarour to show, the entries in the centre, as well as in the right column, are found to be substantially correct, and the whole Nemorandum intelligible. It becomes then a simple précis, or summary, of how the various divisions, etc., had been directed, under Wellington's orders, up to $7 \mathrm{a} . \mathrm{m}$. inclusive, quite irrespective of whether they had reached or were near the places which they had been directed on, by that hour, or not.

Under the second interpretation-the one which it may be said has been universally adopted-the centre column is viewed as very incorrect, because it is taken as indicating the places at or near which Sir W. De Lancey had assumed that the various divisions had by $7 \mathrm{a} . \mathrm{m}$. (and in each instance) arrived, which facts afterwards proved that many of them had not.

We now propose to apply the two interpretations in turn to the details of the Memorandum, beginning with the first, which we believe to be the one which most probably expresses the true purpose of Sir IV. De Lancey, viz., to give IVellington a précis of how the divisions of the Army had been direcled. up to $;$ a.m. inclusive, under his instructions-and nothing more than that.

Let us examine the centre column of the Memorandum from the top downwards, comparing its entries with the Instructions to the Army given by Wellington in his own handuriting." for Colonel De Lancey, and which we refer to here in the "Remarks."

These entries are as follows:-

\section{Entries in \\ Centrc Column.}

sst Division. Braine le Comte.

\section{Rcmarks.}

It had been directed there. Sec 10 p.m. ${ }^{2}$ order (Additional Instructions) of $15^{\text {th }}$ June.

1 See Note with Wellington Despatches of 1852 , fiven on Plate attached.

2 The to p.m. orders, termed After Orders or Additional Instructions, nppear to have becn despatched to Corps between 10 p.m. and midnight on June isth approximately. 
Entries in

Centrc Column. and Division. Braine le Comte.

3rd Division, Nivelles.

fth Division. Aucienarde.

5th Division. Beyond Waterloo.

6th Division. Assche.

5th Hanover'n Hal. Brigade.

$4^{\text {th }}$ Hanover'n Beyond Waterloo. Brigade.

and Division

3 rd Division

(Army of the

Low Countries)

1 The 5 p.m. onders appear to have been despatched between 5 and 7 p.m. on June 15 th.

8 The Orders were (see Edition of the Despatches of $18 \mathbf{5}^{2}$ given on Plate attached) to "march from Brusscls by the road of Namur to the point where the road to Nivelles separates." This point, it is important to notice. is about 2 miles south of Waterion. which would be properly expresind by a "riter in Bruscels as "Beyond Waterloo."
It had been directed there. Sie 7 a.m. order to Lord Hill of June 1 toth (Edition of Despatches of $185^{2}$, but omitted in Edition 1838 ); see Notes below Memorandum. It had been directed there. Sce 10 p.m. order (Adddtional Instructions) of $15^{\text {th }}$ June.

That portion beyond the Scheldt had been directed there. See 5 p.m.' order No. 6 of 15 th Junc.

It had been directed to "Beyond Waterloo." See Io p.m. order (Additional Instructions) of isth June (Edition of Despatches of 1852, onitted in Eclition of 1838 .)

No order for it to proceed to Assche is preserved; but it certainly was sent there. See order of 16th June to Sir J. Lambert, dirccting it to march from Assche on $17^{\text {th }}$ (last Note on Plate).

It belonged to the $5^{\text {th }}$ Division, and had been directed there. See 5 p.m. order of 1 ith June, in Lidition of Despatches of 18,38 .

It belonged to the $6 \mathrm{th}$ Division, and had been directed there. Sie ro p.m. order (Additional Instructions) of 1,5 th fune, Edition of Despatches of 1852 .

Not alluded to under the centre column, but under the right only. 
Entrics in

Centre Column. Sotteghem.

Ist Division and Indian Brigade.

1.-Gen. Dörn berg's Bde. \&: Cumberland IIussars.

Remainder of Braine le Comte. the Cavalry.

Duke of Beyond IVaterloo.
Brunswick's
Corps.

Nassau Corps. Beyond Waterloo.
Remarks.

They had been directed there. Sie 5 p.m. order No. It of isth June (Ed. 1852).

Beyond IVaterloo. They had been directed there. Sec ro p.m. order (Additional Instructions) of 15th June, Edition of Despatches of 1852 .

It had been directed there. Sce 7 a.m. order to Lord Hill of 16 th June, Edition of Despatches of 1852 .

It had been directed there. See 10 p.m. order (Addiitional Instructions) of $15^{\text {th }}$ June, Edition of Despatches of 1852 .

It had been directed there. See ro p.m. order (Additional Instructions) of $15^{\text {th }}$ June, Edition of Despatches of 1852 .

The above comparison of the entries in the centre column of the Memorandum with Wellington's "Instructions," show's that, viewed as a précis of how the army had been directed under those instructions, the Memorandum, in its centre column, becomes substantially correct. $\mathrm{IV}^{\mathrm{H}}$ use the nord "substantially" merely because, in the case of the $4^{\text {th }}$ Division, the whole Division had not been directed on Audenarde, but only that portion beyond the Scheldt (the remainder having been directed to Grammont).

In other respects, and although it was (as we have said) most probably hurriedly compiled, the Memorandum agrees perfectly with the Instructions.

Moreover, the view that the entries in the Centre Column were meant solely to indicate the places which the troops had been directed to (not had reached) is strengthened by Sir De Lacy Evans's explanation of the Centre Column, given with the Memorandum (sce-Plate), for he says: "The Centre Column of names indicates the places at which the troops had arrived, or were moving on." He does not say that all the troops had reached those places; but yet the idea that Sir W. De Lancey implies that they had all cone so, and by 7 a.m., is that (as we shall show later), on which the correctness of the Memorandum has been impugned.

There is no dispute that some of the Divisions, etc., had reached the places entered in this Column, upon which they 
had under orders been directed ${ }^{1}$; but what is here contended for is, that while some had reached those places and some werc still "moving on" them, all had been directed on to them; that it is probably very unjust to Sir William De Lancey to suppose that he meant to imply anything more; and finally, that his Memorandum is but a brief précis, hastily jotted down, and summing up for Wellington's information how the Divisions, etc., up to 7 a.m., had been directed in consequence of his Instructions; and not a calculation of the spot each Division, etc., had reached at 7 a.m.

To turn now to the Right Column.

Comparatively little need be said as to this column, for the insertion by Sir IV.: De Lancey of the words "marching to" before every entry in it, with one exception, shows of itself that the troops had been directed by Wellington's orders upon the places named in it, and also that in Sir W. De Lancey's view, they had not, by 7 a.m., arrived at them.

The "one exception" applies to the entry that the 2nd and 3 rd Divisions of the $A \mathrm{rmy}$ of the Low Countries were, at that hour, 7 a.m., "at Nivelles and Quatre Bras."

The 2nd Division (Perponcher's) was at Quatre Bras; but the 3rd Division (Chase's) did not reach Nivelles until nearly noon.

With regard to this one division, therefore, Sir WW. De Lancey had, it seems, anticipated that it would be "at " Nivelles earliet than it was. The division was cantoned at Roulx and near Binche, some 15 or 16 miles from Nivelles, when, by $5 \mathrm{p} . \mathrm{m}$. Order of $15^{\text {th }} \mathrm{June},{ }^{2}$ it was ordered to "collect at Nivelles."

Therefore it serms perfectly possible that had it ma:ched very early on the i6th, it would, by 7 o'clock, have been nearing, or "at," Nivelles.

But further than this, before we can safely build up arguments as to the correctness or oherwise of this entry, we should require to the original Memorandum. ${ }^{3}$

1 Ropes, though koking at the Menorandum in quite a different light from that here urged, considers it probable, for instance, that by $7 \mathrm{a} . \mathrm{m}$. the $5^{\text {th }}$ Hanovcrian Brigade had reached $\mathrm{Hal}$; the 6ih Division. Assche; the Ist Division and Indian Brigade, Sotteghem; and the fth $^{\text {th }}$ Division (i.e., a portion), Audenarde.-(Kopes, pp. 111,112 ).

- See Despátches, Edition of 1852, No. 10 (on Plate attached).

9 This original, lost at Waterko, we can of course scarcely now hope to see; and Sir De Lacy Evans's oopy seems also now to have disappeared. It is not among the documents at Apsley House : Colonel Gurnood is siid to have returned all MSS. to the onners; and Sir De Lacy Evans's papers have not, it is understood, been preserved. What ernors may creep into printed copies of documents is uell illustrated by mentioning that in Wellington's Waterbo Despatch of Igth June, 1815, as printed in the Despatches (Editions 1838 and 1852 ), three "Eagles" are said to have been captured at Waterbo, whereas "tic'o" Eagles is uritten in the original. Ako see as to this the "Notes" below the Memorandum on Plate attached. 
Everything turns upon whether the word "at" (which, throughout the Memorandum, is used solely in this place) is correctly copied and printed from the original. If, for instance, the "at" was "At." (meaning "about") the sense of the entry is altered.

IVe can get, perhaps, some clue as to why the Right Column was added to the Memorandum, through Sir De Lacy' Evans's statement that "the column on the right of the paper indicates the places the troops were ordered to proceed to, at 7 o'clock a.m." (on i6th June).

It is to be noted that the orders to proceed to places entered in the Centre Column were issued at various hoursprincipally on $15^{\text {th }}$ June, at 5 or 10 p.m.; and only those for the 2nd Division and Cavalry (to proceed to Braine le Comte) on i6th June, at about 7 a.m. Also that all the orders to proceed to places in the Centre Column were given in Wellington's written Insiructions, or by oritten Memorandum signed by Sir IV. De Lancey (of which copies have been preserved and printed in the Despatches), ${ }^{1}$ while we possess no written copy of any order to proceed to places entered in the Right Column, with the exception of that of the 16th June (hour not given) for the Ist Division of the Army of the Low Countries, and the Indian Brigade to move from Sotteghem to Enghien. IVe know that the troops did proceed towards the places entered in the Right Column; we know, from Waterloo letters, that some of the orders to do so reached the marching divisions on the line of route, brought by aides-de-camp, or mounted meñ, and perhaps verbally; and he have Sir De Lacy Evans's statement ${ }^{2}$ that the troops were ordered to these places "at $;$ a.m.," but there are no writ:en copies of Wellington's instructions, or Sir IV. De Lancey's orciers in consequence of them, for the troops to proceed onward to Nivelles, Quatre Bras or Genappe on the 16 th June. ${ }^{3}$

To drau too many inferences, as to the cause of there being tho columns (centre and right) of places on the Memorandum. would not be justified; but it may, perhaps, not be unreasonable to suggest that Sir W. De Lancey may, as rould have been natural, have begun his Memorandum-or précis, as ne view it-by jotting down, in the Centre Column, those places to which the divisions, atc.; had been directed under the Duke's Instructions and his own written orders, in pursuance of them; and that, having done this, he received, at the last moment, a batch of orders for the troops to be moved on still further to the places which he then added to the Memorandum (in the Right Column).

1 Set Ropes as to this also-p. 87 and 82 .

2 Some have viewed this statement as an crror, but there is no proof that it is; and it certainly must carry ueight.

3 There ate written orders (issued on the 16 th from Genappe) for troops to procced to Nivelles and Quatre Bras on the $1 ;$ th, but this is quite another thing. 
We must now consider the second interpretation, which the title of the Memorandum will bear. The crucial difference between this and the first interpretation, which we have already discussed is that, under this (the second interpretation) the divisions, etc., are all supposed to have reached (and not merely been directed on) the places entered in the Centre Column. This, although it involves repetition, we emphasize again, because it is upon this supposition that the Memorandum has been condemned.

IVe propose to take Ropes, whom we have quoted before, one of the most careful, valued, and widely-read writers upon the IVatertoo Campaign, as expressing the view of many others, or it may be said, without exaggeration perhaps, the universal viex, in applying the second interpretation to the Memorandum.

He urites ${ }^{1}:-$

"It (the Memorandum) purports, in our opinion, to be a statement by W'ellington's Chief of the Stafi, of the probable positions, at 7 a.m. of the 16 th June, of the various divisions, and of their respective destinations." 3

Acting upon this conception he compares the real position of the troops at 7 a.m., as ascertained afterwards, with the critries in the Centre Column, in order to show the faults of the Memorandum. He points out that certain of the Divisions, etc., had not reached the positions indicated in the Centre Column, and with regard to the $5^{\text {th }}$ (Picton's) Division, including the Hanoverian Brigade and the Duke of Brunswick's Corps, which all formed part of the Reserve, remarks that instead of their being "Beyond Waterloo," they were at 7 a.m. "some six miles on the Brussels side" of it.

But Ropes, at the same time, alluding to Wellington's additional orders, issued at 10 p.m. on $15^{\text {th }}$ June, says (p. 79) : "No orders acere issucd to the Rescrues."

This makes it apparent that he had not happened to see these orders to the Reserve, detailed in the 1852 Edition of the Despatches. 5 Yet they evidently were issued-to proceed to a point along the Namur road to where "the road to Nivelles separates," i.e., to "beyond Waterloo."

1 Ropes, p. 86 et seq; and p. 110-115.

2 Referring, apparently, up to this point, to the cntrics in the Centre Column.

${ }^{3}$ Reterring, apparently, to the entries in the Right Column.

The Italics are ours.

- But not, as we have before said, in the 1838 Edition. Ropes also mentions (p. 82) that no hour is given on the order to Hill of the morning of 16th June to nove the and Division to Braine te Comte-it is not given in the 1838 Edition, but is in that of 1852 as 7 a.m.

- The reason for this order seems clear, for from this point it could afterwards be moved either along the rond to Nivelles. or along that towands Namur, which passes through Quatre Bras and Charleroi, as Wellington might decide. 
Ropes, not being aware that the troops in Brussels, forming the Reserve, had been so directed, could not, of course, have imagined that Sir $W^{T}$. De Lancey had used the expression "Beyond Waterloo"-which occurs five times in the Memorandum-in any other sense than that the troops referred to were in this situation, at 7 a.m.

But as the 1852 Edition of the Despatches is evidence that they were directed to "Beyond Waterloo" in the "Additional Instructions" of 10 p.m. on 15th June, this tends materially' to strengthen the first interpretation of the Memorandum which we here support.

As this 10 p.m. order was not delivered to the troops in Brussels till between 10 p.m. and midnight, and Picton's Division of the Reserve (the 5 th) marched at $4 \mathrm{a.m}$. On the $36 \mathrm{~h}$, there is little doubt that whatever further orders they received afterwards, they left Brussels under it.

It has been thought useful to point out the differences which exist between the first and the Revised Editions of the Wellington Despatches. They have led to no little misconception as to certain details; and the present writer has more than once missed some points of interest by not consulting the latest as well as the first editions of this and other works (such as Siborne's History of the Campaign).

It is important to consult all, but not always easy. Every library does not possess the latest edition; and to those who are on the Continent, in America, or elsewhere abroad, and have not access to the British Museum Library, the difficulty of referring to the latest edition is, of course, often increased.

As a possible explanation of how it may have happened that, in what purport to be copies of the same original, but lost " "Instructions" for the Army, issued by Wellington on 5.5th, 16 th, and 1 th Junc, there are differences between the ${ }_{1} S_{3} S$ and 1852 editions of the Despatches, it may be remarked that what appears in the 18.38 edition is stated to have been furnished to Colonel Gurwood by Lord Hill and certain others,

If may be mentioned here that the only dxcument in Sir W. De Lancy's possession when he was mortally wounded at Waterbo which was recovercd, was a plan of the ground on which the battle was fought on the teth Junc, found in the breast of his tunic, stained with his blood. This plan had been made by Cotonel Carmichael Smyth, R.E., and other officers sone time previously. Wellington on $17^{\text {th }}$ june sent in to Brussels for it, and then indicated on it to Sir W. De Lancey by some rough pencil marks the pasition which he wished taken up that night. It would now be of great military interest, but cannot be found by Col. Carmichael Smyth's descendants. A lithograph of a portion of it appears in C. D. Yonge's "Life of the Duke of Wellington," published in 1860 , when it was in posscssion of Lady Carmichael Smyth.-See Lady De Lancey"s "A Wicek at Waterloo," (Ig06), pp. 110-112-and a tracing of the whole is preserved in the Royal United Service Institution with interesting notes on it by Major Oldfield (see p. 5. Note 3 ). 
to whom they had been addressed, while what appears in the 1852 Edition, so far, at all events, as the 5 and 10 p.m. orders of igth June are concerned, was furnished by Sir De Lacy Evans, who was with Sir IV. De Lancey when they were issued.

The Reserve was under Wellington's direct command, which may account for Lord Hill, in the copy sent, not having preserved the orders to it, while Sir De Lacy Evans preserved a fuller copy of the entire paper. This, of course, however, is conjecture only.

The view that the De Lancey Menorandum is but a hurried précis of WVellington's directions to the Army, up to 7 a.m. on 16 th. June inclusive, is strengthened by a consideration of the moment when the paper was put together. Would Sir II. De Lancey have been very likely, under the situation at that hour prevailing in Brussels, to have calculated marches and distances of the various divisions? Yet without doing this he could not hope to indicate even roughly in the Centre Column the precise positions which those divisions had reached,

He might have done so certainly, but it must be remembered that orders had been going out at intervals during the preceding afternoon and night till midnight; that the more distant columns were far off, and that orderlies reaching them would in several instances hardly have returned, by 7 a.m., to report the hour of their delivery.

Is it not as, or even more, likely that Wellington, before setting out for the field from Brussels, should have asked for a brief précis, in form convenient to refer to, of how the army: had been directed, and was therefore moving, under his orders up to that time? Or, had he not himself asked for it, that Sir IV. De l.ancey should have put it together for him?

Further, what is less likely, in reality, than that Sir WV. De Lancey, a Staff Officer of long Peninsular experience under Vellington, should compile a palpably incorrect and misleading paper for his Chief.

In forming his Head-Quarter Staff for the Waterloo campaign, Wellington had selected Sir WV. De Lancey for the post of Deputy Quartermaster-General, which was practically that of Chief of his Staff. Though young for this post (about 35 years of age), he had served for ten years in the QuartermasterGeneral's Department; and from Corunna to Toulouse had distinguished himself in the field. He was not one of the untrained officers of Wellington's Staff.

1 Serious delays occurred in the delivery of some of the orders. For instance, the order to the and I Division to march from Ath was wot delivered to Ilill, who had gone to Grammont, before 3 a.m. On the strith and one of his regiments (the 52 nd) received theirs at to a.m. 
Sir Augustus Fraser writes of him, after Waterloo:-

"This is our greatest loss-none can be greater, public or private" ; and Vellington:- "This officer is a serious loss to His Majesty's service, and to me at this moment."?

We have now, perhaps even in somewhat tedious detail, put forward what has led us to think that this Memorandum, by Sir WV. De Lancey, was drawn up merely as a précis, not of the places which the troops had necessarily reached, in any case, but of those they had been directed to in Wellington's Instructions.

If this conception of the intention of its compiler is correct, then the idea that the paper is incorrect and misleading falls to the ground; for, as a précis of orders, and especially under the circumstances in which it was hastily jotted down, it both fulfils its purpose and is terse, comprehensive, and complete.

In case the interpretation of it now suggested should appear too simple, we know that occasionally what may have seemed cryptic is the reverse, and that, as in the instance of the inscription upon the ancient stone, which caused the celebrated controversy among the members of the Pickwick Club, ${ }^{3}$ its solution may be a very ordinary one.

Let us now consider the question of whether it is probable that Wellington turned to this Memorandum before writing his letter to Blïcher, and that its entries misled him.

Of course, if he understood the Mlemorandum to be but a précis of where the troops had been directed, and the Centre Column not to imply that they had by 7 a.m. reached the places entered in it, then there was nothing misleading to him in the paper, for it was a practically correct summary.

But let us suppose that he did not so understand it, and could have taken the Centre Column to indicate that the troops had reached the places entered in it ; and, under this supposition, compare Wellington's letter with the Memorandum.

The letter, translated from the Franch, in which it was written, runs thus :-

\section{MIL De.IR PRINCE,}

Upon the heights behind Frasne, June 16 th, 1815 , at half-past ten.

My army is situated as follows. Of the Corps of the Prince of Orange, one Division is here, and at Quatre Bras, the remainder at Nivelles. The Reserve is on the march from Waterloo to Genappe, where it will arrive at noon. The English Cavalry nill be at the same hour at Nivelles. Lord Hill's Corps is at Braine le Comte.

1 l.ctters of Sir Augustus Fraser (nho commanded the Horse Artillery at Waterloo).

2 Wellington Despatches, Edition of $185^{2}$, Vol. VIll., p. 150.

3 Papers of the Pickwick Club, by Charles Dickens, Vol. I., p. 166 et seq. 
I do nut see any great force of the enemy in front of us; and $I$ await news of Your Highness, and the arrival of troops, to decide upon my operations for the day.

Nothing has appeared in the direction of Binche, nor on our right.

\section{Your very obedient servant,}

WELLINGTOK.

The first statement in the letter is :-

"The Corps d'Armée of the Prince of Orange has a Division here and at Quatre Bras, and the remainder at Nivelles."

So far the letter is in agreement with the Memorandum; but Wellington had reached Quatre Bras himself at about 10 a.m., half-an-hour or so before he wrote to Blücher; and the Prince of Orange, who commanded the Corps referred to, had been there for several hours, ${ }^{1}$ and Wellington is said to have joined him there, inspected his position, and presumably conferred personally with him, or his staff.

Why should it be supposed that he took his information as to this Corps at 10 a.m. from a Memorandum compiled in Brussels shortly after 7 a.m., when he could see what troops were in and about Quatre Bras (stated correctly in his letter) with his own eyes; and, as far as the remainder of the Corps" is concerned, which was marching towards Nivelles, could obtain later and surer information as to when they might possibly reach that point, from the Commander of that Corps or his Staff?

The next statement is:-

"The Reserve is on the march from Waterloo to Genappe, where it will arrive at noon."'

Wellington had ridden past the Reserve, on his way to Quatre Bras, probably about 9 a.m. ${ }^{3}$ He knew exactly where they had been at that hour. Why should he turn to a Memorandum written soon after 7 a.m. for his information as to the Reserve?

The next statement is:-

"The English Cavalry will be at the same hour (i.e., at noon) at Nivelles." In the Aemorandum "Braine le Comte" is placed in the Centre Column with reference to the "Remainder," i.e., the bulk of, the Cavalry (Dörnberg's Brigade and the Cumberland Hussars having been already dealt with).

1 Ropes, p. 106. Hooper, p. 101. Sir Herbert Maxwell's "life of Wellington," Vol. 11. pp. 16-19.

2 The 3 rd Division of the Army of the Low Countries; and the ist and 2 nd Divisjons (British and Hanoverians).

W Waterloo Letters, pp. 23, 357, $3 S_{5}$; and Historical Records of the 79th Highlanders; (see Ropes also, p. 10\%, on this head).

-The Reserve, by some mistake, remained halted near llaterbo longer than he had intended, or it woukd have been at Quatre Brac carlier. 
Now, had Wellington turned to this Niemorandum and imagined that the entry "Braine le Comte" implied that the remainder of the Cavalry had arrived there at $7 \mathrm{a} . \mathrm{m}$., how could he possibly have written that it would not reach Nivelles till noon? This would be a calculation that it would take 5 hours to reach Nivelles from Braine le Comte (to miles).

The last statement is :-

"Lord Hill's Corps is at Braine le Comte."

As to this Corps, however, "Braine le Comte" is placed in the centre column with reference to the and Division only, "Audenarde," not Braine le Comte, being placed with reference to the $4^{\text {th }}$ Division, and "Sotteghem," not Braine le Comte, with reference to the ist Dutch Belgian Division and the Indian Irigade. $A$ s to this Corps, as Ropes has observed, Wellington could not have consulted the Memorandum.

Had he gone by it, and understood from it that the $4^{\text {th }}$ Division had been at Audenarde at 7 a.m., and the ist Dutch Belgian Division and the Indian Brigade at Sotteghem, then his statement that they were at Braine le Comte when be wrote (at 10.30 a.m1.) would have been equivalent to a calculation that Infantry could march from 25 to 30 miles in 3 hours.

The above considerations not only tend to confirm the impression that the places entered in the centre column of the Aleniorandum were merely those to which the divisions had been directed, and not which they had reached; but further to show that the Nemorandum in whatever light we look at it, i.e., whether interpreted either as a précis of orders simply, or in its hitherto accepted light, could scarcely have misled ivellington, or influenced him, to any extent whatever, in his letter to Blücher.

Wellington, when he wrote that letter, undoubtedly $c x-$ pected the Army to be more advanced than it was. Delays which had occurred in the delivery of his orders, sent out from Brusscls in many cases after dark; delays in the troops getting off upon the march; and delays by the overcrowding and blocking of the roads along the line of route, all tended, it may be fairly assumed, to mislead him and others also as to the exact position of portions of the army at $10.30 \mathrm{a} . \mathrm{m}$. In alluding to Hill's Corps he probably never meant to imply that those portions beyond the Scheldt could have been at Braine le Comte at that hour-the distance entirely precluding the possibility of that.

These questions, however, are apart from the purpose, the correctness, or the effect, of the "De I-ancey Memorandum," to which we confine ourselves here.

1 He writes (p. I 80 ) "The Duke had not the authority of the "Dispo sition' for the statcment made in his letter, as to these portions of lord Ilill's Corps"-by "these portions" meaning portions other than the and Division. 